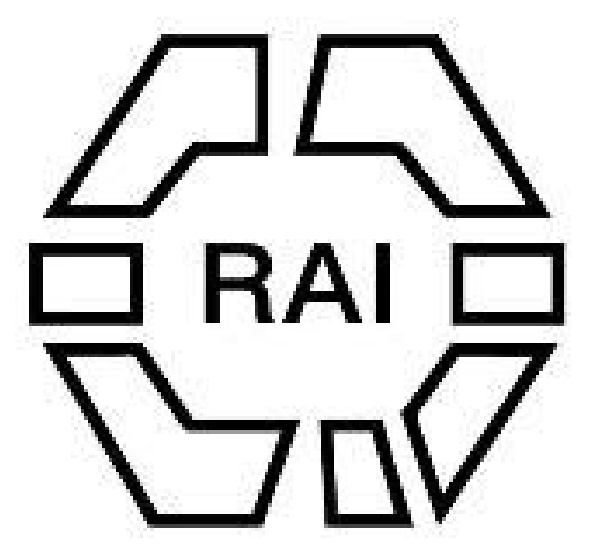

\title{
WILEY
}

\section{The "Historicity" of Arunta Traditions}

\section{Author(s): A. Lang}

Source: Man, Vol. 10 (1910), pp. 118-121

Published by: Royal Anthropological Institute of Great Britain and Ireland

Stable URL: http://www.jstor.org/stable/2787341

Accessed: 27-06-2016 02:42 UTC

Your use of the JSTOR archive indicates your acceptance of the Terms \& Conditions of Use, available at

http://about.jstor.org/terms

JSTOR is a not-for-profit service that helps scholars, researchers, and students discover, use, and build upon a wide range of content in a trusted digital archive. We use information technology and tools to increase productivity and facilitate new forms of scholarship. For more information about JSTOR, please contact support@jstor.org.

Royal Anthropological Institute of Great Britain and Ireland, Wiley are collaborating with JSTOR to digitize, preserve and extend access to Man 
The "Historicity" of Arunta Traditions. By A. Lang.

A most difficult point in Arunta social organisation, a point which probably colours the mythic traditions of the people, has received little attention. How do the Arunta come to possess, as they do, "local totemic groups?"* With a system of male descent of the totem name, local totem groups, like Highland clans, necessarily tend to be mainly of one name, totem name, or patronymic. But the essence of Arunta totemism is the accidental acquisition of the totem name. Father, mother, and each child may be all of different totem names. Yet "there will be one area which belongs " to a group of men who call themselves Kangaroo men, another belonging to Emu " men," and so on. "The largest, represented by exactly forty individuals, men, " women, and children," is the Wichetty Grub group at Alice Springs, who possess " about 100 square miles." $\dagger$ Of these Wichetty Grubs, thirty-five are of the BultharaPanunga phratry, only five are Purula-Kumara. $f$ How in the world do they all come to be Wichetty Grubs? It is impossible that each and all of them should have been conceived in a Wichetty Grub oknanakilla, or centre of Wichetty Grub ratapa, "spirit children," or "spirits" (or other beings-as in Mr. Strehlow's accounts, not regarded as "spiritual"). Yet "the local groups . . . . consist to a large extent, " but by no means exclusively of men and women of what is commonly spoken of as a " particular totem."

It is not easy to understand how this happens when mere accident determines the totem of each individual. For example, we are offered the case of a family; the father is Wichetty Grub, wife is Lizard, one son is Grub, the other is Lizard. In another case, father, mother, and one son are Grub, the other son is Kangaroo.\| In a third case, with Eagle Hawk father, and Hakea flower mother we have Grub, Emu, Eagle Hawk, and Elonka sons and two Grub daughters, and the totems vary as much in another instance ; Hawk, Grub, Kangaroo, Lizard, Emu, Water.

In such circumstances, how can there be in each local group a large majority of one totem name? "The totems are strictly local," come by chance? Is it possible that while each local group is really made up of persons of many totems (as where female descent prevails) the entire group is styled "Wichetty Grub" in compliment to the members who inherit or possess, and perform the most notable totemic ceremonies? This is the only solution of the problem at which I can conjecture. Meanwhile the local groups are certainly spoken of as if, in each case, they were mainly of one totem, which they can only be where male descent of the totem name prevails, and among the Arunta it does not exist. While "the totem names are apparently mixed up in the greatest confusion possible "** how are a hundred square miles the property of one group of Wichetty Grubs? We hear of "a certain number of local groups of individuals belonging to particular totems" $\dagger \dagger$ but it is not apparent how such groups can exist, when the individuals may be and are, of any number of totems.

Now Arunta myth speaks of the earliest human groups as consisting in each case of individuals all of one particular totem. If we hold that such traditions are historically worthless, we can explain them, in a way, by saying that they reflect upon the past the condition of affairs in the present. In the past, as in the present, there would be one area which belonged to one group of men "who called themselves kangaroo men, or emu men, or Hakea men," as is now the case. $\neq$ But how it can be the case, when each person's totem name is derived by pure chance, is what one fails to understand. Still, granting that it is the case, as Messrs. Spencer and Gillen

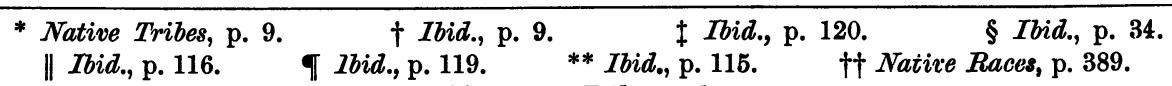


frequently state that it is, Arunta mythic fancy merely transfers the conditions of the present to the past, with a slight exaggeration.

But Dr. Frazer, with Messrs. Spencer and Gillen, finds us "driven to conclude that these traditions . . ." (he is speaking of traditions of free and habitual totem-eating) "do faithfully preserve a recollection" of the manners which they describe.* This must apply, I think, to one part of the tradition of usages, as much as to another. If so, the ancestors of the Arunta lived in endogamous totem groups, while, according to the legends, they made free with any women of other totems whom they came across. They had totems because they were in many, not all, cases, developed out of the animals which were their totems. As these animals were in groups, so were they, and they must wed their own women, till they came across others of other groups.

To me these traditions appear to be, not historical, but dictated by the logic of fancy. The Arunta meet the question, "How did men become totemic?" by saying that the "eternal" or "self-existing" Ungambikula made them so, out of creatures "which were in reality stages in the transformation of various plants and animals into human beings." $\dagger$ They were thus made "in local groups of individuals belonging to particular totems." Here the present is reflected into the unknown past; in the past as in the present totem groups were local.

Then the next question is, "Whom did the men marry?" and the answer takes for granted that they had wives of their own local totemic groups.f What other women could they procure before their wanderings began?

The legend cannot prove, or suggest, that the Arunta were never, in the past, forbidden to marry within the totem. They may do so now, and their myth reflects that license on the mist-screen of the unknown past, at a supposed time when only women of their own totem were accessible to the men of each group.

How can we take as historical evidence fables which transplant, into the first dawn of humanity, the terminology of the present classificatory system? No sooner was a lizard man made out of an Inapertwa or animate bulk, than he possessed an "Okilia or " elder brother," $\$$ being himself the Itia or younger brother, I suppose. He could not be that till after the phratry arrangement and its rules were made!

I confess myself unable to understand how scholars should take such stories as these for historical evidence on any point of prehistoric manners. As in Dieri myths of the origin of exogamy, the rules are ascribed to the wisdom of some sages-because now sages suggest emendations in rules, so the Arunta myths throw back the classificatory system into the period of the indeterminate Inapertwa which could have no human relationships. The tales speak of totemic endogamy as habitual. What else can we expect from people who for long have practised intra-totemic marriage, and whose myth of the origin of totemism assumes that men originally lived in separate local groups, each of one totem only?

The traditions of the Middle Alcheringa period cheerfully and naturally assume the existence of the Four Class names, among a local Hawk totem group.\| Every one of the set alrealy belongs to one or other of these exogamous intermarrying divisions, just as the classificatory system of relationships already exists. All this was at a time when Inapertwa or undifferentiated animated bulks were still thick on the ground. $\uparrow$ The Arunta in general adopted the Four Class names from the Little Hawk group,*** and if their presence does not mean the presence of the Four Class system, what ean it mean?

Nothing is said in the legends about phratry names. These are invariably, I

* Totemism, Vol. I. p. 238. § Ibid., p. 390.
† Native Tribes, pp. 388-389.

\|l Ibid., p. 394.

** Ibid., p. 396.

[ 119 ] $\ddagger$ Ibid., p. 390.

T Ibid., p. 395 et seq. 
think, found in Australia, where the phratriac system without the "classes" exists. Among the Arunta, phratry names are obsolete, and so the myth says nothing of them. They are never absent in Australia, I think, where the four class names have not been adopted. Dr. Frazer* argues thus: It appears to be commonly supposed that names for the two moieties (classes), or "phratries," must formerly have existed and afterwards been forgotten, from which again it has been inferred that the marriage system of the Arunta is late and decadent. The analogy of the sub-classes points to the opposite conclusion, namely, that the marriage system of the Arunta is developing, not decaying, for if four of the eight sub-classes among them are only receiving (not losing) names at the present time, and in some places are still nameless, we seem bound in consistency to suppose that similarly the two classes or moieties have not lost their names, but, on the contrary, have not yet received them.

My reply is that people, if they get the chance, may borrow what they need, but not (save to be in the fashion), what they do not need. Arunta, who had no names for certain " degrees" already among them "forbidden," appear to be borrowing, even now, the names by which part of their tribe denominate these degrees. But the Arunta need no names for the two main exogamous divisions of their tribe. These are indicated, in each case, by a pair of the class names. If I am not wrong, long before the phratry names of the Kamilaroi were discovered, the class names, Hipai, Muri, and the others served the turn. When the phratry system, according to Dr. Frazer, was instituted, a man " had only to ascertain from any particular woman "whether she belonged to his group" (phratry) " or the other group, and his course " was clear." $†$

In this case the naming of the phratries was a great and obvious convenience, and I am unaware of any Australian tribe with the phratry system, and without the classes, which does not retain the phratry names. But when the classes have long done all the work, the phratry names, being useless, tend to disappear. In what conceivable circumstances could the Arunta now find it convenient to borrow or invent phratry names?

It is universally acknowledged that the Four Classes are a development later than the two phratries. On them is thrown all the work, and it is natural that the phratry names where eight classes exist should become obsolete. It is not natural that, where they are perfectly useless, they should ever be needed and come into existence, that is, where the Four Class names exist. The Arunta legends are silent about phratry names, voluble about class names, because these exist and are important; while the phratry names, being useless, are forgotten, as among the Kurnai.

In the traditions, Ertnatulunga, or sacred storehouses of churinga, existed among certain Inapertwa, who were operated on and made into men of the Emu totem. $\neq$ The Arunta myth-maker is unspeakably unhistorically minded! Inapertwa perform the great Engwura ceremony! §

The class names, so far, are not spoken of in connection with restrictions on marriage.\| They are merely introduced, I presume, because the myth-makers can scarcely think of men without them, yet they see that they must have had a beginning; how they know not, so attribute them to Little Hawks. Why the myth makes the groups live so freely, or solely, on their own totems, though the wild cats lived on the hakea flower, $\mathbb{T}$ and quails on grass-seeds, ${ }^{* *}$ I do not pretend to know. At no time can a group have lived mainly on its own totem, of which the season is often brief. As to marriage rules, Purula men and Kumara women, in the Middle period, actually cohabited, a thing now wholly forbidden. In other cases the present is reflected on the

* Totemism, Vol. I, pp. 264, 265.

$\ddagger$ Ibid., Vol. IV, pp. 391, 397.

ๆ Ibid., p. 403. $\dagger$ Ibid., Vol. IV, pp. 113, 114.

$\S$ Native Tribes, p. 401.

** Ibid., p. 403.
II Tbid., p. 402. 
past, not so in this. Apparently the myth could not keep the class names out of the story. But it had also to account for the institution of the class restrictions, and, in its usual confused way of thinking, represented the class restrictions as later than the class distinctions of name. Messrs. Spencer and Gillen can only explain the tradition "on " the supposition that the class names which were given by the Ullakupera" (Little Hawk) "men entailed restrictions upon marriages, but restrictions which were of a " different kind from those introduced at a later period."* But no restrictions of any kind have yet been mentioned, nor can we imagine what manner of restrictions by four class could exist except such as do exist.

We have shown that the legends are absolutely subject to no logic but that of fancy. The myth introduces class names because the mind is so familiar with them, and, by an afterthought, accounts for the class restrictions which the presence of the names already implies. A wise man of the Emu group simply invented the class restrictions; the tribe voted in favour of his measure, and that is all the explanation. $\dagger$ "The legislator in his wisdom" decreed exogamy, and we are still asking, why? Ghosts of theories rise at call, but each in turn vanishes, "following dark" ness like a dream."

I am debarred from quoting the traditions as containing history. But in one instance they chance, I hold, to deviate into truth. "The traditions of the tribe "point back to a time when, for the most part, the members of any particular " totem were confined to one moiety of the tribe." $\ddagger$ Thus, " in the Alcheringa, all the "Wichetty Grub men were Bulthara and Panunga."

If so, the Arunta have passed out of normal totemism, in which each totem is strictly confined to one phratry only. I have no doubt that this is true, but not because tradition says that it is true. Tradition merely exaggerates the present state of things, in which "the great majority of" Wichetty Grub men do belong to the nameless phratry of the Bulthara and Panunga classes. How this comes to be so, why only a small minority of the people of the totem name are "born into " the wrong class" $\|$ Messrs. Spencer and Gillen tell us. It is owing to the " system according to which totem names are acquired" $"$ now. If totem names from the first were acquired, as now, by chance, each totem would be almost equally distributed between both "moieties." But quite the reverse is the case. How this occurred the believers that the Arunta never passed through normal totemism are repeatedly but vainly invited to explain. Till they do produce a viable theory their system is not to be accepted. I do not observe that Dr. Frazer ever alludes to this crucial problem.

'The phratries of the northern tribes, to-day, are locally separate. So, according to a myth given by Mr. Strehlow (Theil I, pp. 6, 7), were the phratries of the Arunta originally.

A. LANG.

\section{Polynesia.}

Woodford.

Note on a stone-headed Mace from Rennell lsland. $B y C$. $M$. Woodford, F.R.G.S., Local Correspondent of the Royal Anthropological Institute.

After several years' search, one of the stone-headed maces from Rennell Island has come into my possession, through the munificence of Dr. Northcote Deck, of the South Sea Evangelical Mission, who recently visited the island.

Mr. Basil Thomson, in The Discovery of the Solomon Islands, page xl,** appears to connect these maces with the maces headed with a nodule of iron pyrites and
* Native Tribes, p. 418.
$\dagger$ Ibid., pp. 420, 421.
$\ddagger$ Ibid., pp. 120, 121.
$\S$ Ibid., p. 125.
\|l Ibid., p. 125.
ๆ Ibid., p. 126.

** The Discovery of the Solomon Islands, Hakluyt Society, London, MDCCCCI. 